\title{
TAX AGRESSIVENESS IN FAMILY FIRMS: CAN CORPORATE GOVERNANCE MITIGATE IT?
}

\author{
Oleh: \\ Arie Pratama \\ Departemen Akuntansi, Fakultas Ekonomi dan Bisnis, Universitas Padjajaran
}

\begin{abstract}
Every taxpayers objectives is to minimize the tax paid to government. Few business tried to avoid tax more agressively than the others. This research will tried to investigate whether the family firms are more tax agressive compare to non family firms. Tax agressiveness might be reduced if there is a working governance structure. This research will also investigate whether the governance structure (i.e size of board of director, proportion of independent director, external audit firms, and audit committee) would significantly reduced the tax agressiveness. To control the results, researcher used size, profitability and leverage.

This research was quantitative explanatory research. Researcher will analyzed 15 out of 57 family own-business in Indonesia, and make a comparison with non family firms. Researcher examined the financial statements and annual report from year $2011-2015$. The research will used multiple regression analysis as a data analysis tools. This research will produce tax agressiveness analysis of family firms, non family firms, and combination of both firms.

The research showed that, contrast to the non family firms, family firms had agressive tax avoidance scheme. The research also showed that corporate governance in family company in fact, increasing the agressiveness o tax avoidance, while non family firms corporate governance reduced the agressiveness of tax avoidance. Overall this research showed that family business need to improve the governance structure to control its agressive tax avoidance. Keywords: Corporate Governance, family Business, Ownership, Tax Avoidance

\section{INTRODUCTION}

Indonesia still struggle to increase the level of tax compliance. Based on the report made by Directorate General of Tax, Ministry of Finance in year 2016, tax compliance ratio in Indonesia is $60 \%$. Still far below the target of $75 \%$. Tax ratio of Indonesia also lower compare to other South East Asian countries. Based on the report made by Statistics Bureau of Indonesia,

Indonesia's tax ratio is still $11 \%$ in year 2015, while other neighbouring countries, such as Singapore and Malaysia has higher ratio, $24 \%$ and $18 \%$ respectively. Indonesia tax receipt also never achieving the target in the last 5 years $(2010$ - 2015), even tax revenue realization in year 2015 is only $85 \%$ of the target. The lower amount of tax revenue might be caused of several factors. One of the factors was tax avoidance
\end{abstract}


practice conducted by Indonesia's taxpayer, especially corporate tax payer. Tax avoidance practice conducted to reduce income tax payable of the company legally. Company used several methods to conduct tax avoidance, but the most common method is to use the accounting methods (M.Zain, 2005; Jones, 2012). Company also used estimation to increase the expenses and creating several allowances to reduce the income.

Tax avoidance level vary across the companies. Previous research showed that several companies tend to do tax avoidance compare to the others. The reason might related to economies of scale and complexity issues, e.g if the company has more business unit, the tax charged might be increased (Mills et al. 1998; Rego 2003; Chen et al. 2010). Many researcher used different proxies to represent company characteristics. Minnick and Noga (2010) used size, book-to-market ratio, profitability, leverage, discretionary earnings, and ratio of advertising expense and capital expenditure as a proxy for firm characteristics. Taylor and Richardson (2013) used firm size, leverage, capital intensity, inventory intensity, $R \& D$ intensity, return on assets, and industry sector and year effects. Beside the company specific factors, several research also showed that corporate governance can mitigate tax avoidance practice. Desai and
Dharmapala (2006) argue that tax avoidance scheme can be overcome by a good governance system. Previous researcher used many proxies to represent corporate governance, Minnick and Noga (2010) used board composition, entrenchment, board compensation and executive compensation. Wahab and Holland (2012) used ownership structure, board structure, and compensation structure. However, as the researcher analyzed, several previous research still showed some inconsistencies of results.

This research will analyze family firms tax avoidance practice. Several previous researchs still produce different result. Private family firms appear to be less tax aggressive compared to nonfamily firms (Steijvers \& Niskanen, 2014; Chen et al., 2010; Desai and Dharmapala, 2006; Monterrey and Sánchez, 2010). Steijvers \& Niskanen (2014) argue that family firms tend to avoid practice that can damage the company reputation, including agressive tax avoidance. All of previous research conducted in high alignment country, in which financial accounting and tax reporting has similiar requirements and principles. Indonesia has materially different financial accounting and tax reporting rules, so it is interesting to see if the result in Indonesia will be different from previous research.

This research tried to elaborate the company characteristics and corporate governance as a variable that affecting 
aggressive tax avoidance practices. This research will used several proxies used by previous research, so it can give broader picture of measurement of company characteristics and corporate governance. This research will also take 5 year period (2011 - 2015), so it can gave more recent view of tax avoidance practice in Indonesia. This research will give a new insight to the tax avoidance practice and hopefully can give more clear view about tax avoidance practice between family and non family firms in Indonesia. Family firms and non family firms will be a major comparison in this research. The next section of the paper will present relevant literature review and is followed by sections on research methodologies, results, further analysis and finally the conclusion and suggestion for future research.

\section{LITERATURE REVIEW}

This section will discuss about relevant literature review regarding tax avoidance, company characteristics, and corporate governance. This section will present a clear link between variables studied in this research, as well as a theoretical foundation of this research.

\subsection{Tax Avoidance and Firm Motivation}

Jones (2012) decribe tax avoidance as consists of legitimate means of reducing taxes. In a company persepectives. Jones (2012) also argue that the objective of business decisions is to maximize the value of the firm, therefore If a transaction results in an increase in any tax for any period, the increase (tax cost) is a cash outflow, and if a transaction results in a decrease in any tax for any period, the decrease (tax savings) is a cash inflow. Tax cost must be lower than tax savings, so the company can increase their value. Hanlon and Heitzman (2010) argue that tax avoidance had define very broadly. The usual theme of tax avoidance is about uncompliance or agressiveness. Danny and Darussalam (2007) defined the agressive tax avoidance as: "unacceptable method of reducing income taxes from point of view of tax authority, although it is legal to conduct it". They also describe several methods to avoid tax aggressively, e.g thin capitalization, transfer pricing, or treaty shopping.

Theory of corporate tax avoidance discussed heavily in several previous research. Hanlon and Heitzman (2010) elaborate agency theory to explain tax avoidance behavior. They stated that in the corporation, there is a separation between ownership and control. Manager will act and think that if tax avoidance is a good activity, then the owners ought to structure appropriate incentives to ensure that managers make tax-efficient decisions. Desai and Dharmapala (2007) also stated 
that interaction of corporate governance and tax planning will make different view of firm value. Investor will view aggressive tax avoidance to reduce firm value, especially in a company with lack of good corporate governance. However, in a company with strong corporate governance, tax avoidance will have no significant effect to firm value.

This research will used effective tax rate (ETR) as a measurement for tax avoidance. Hanlon and Heitzman (2010) stated that effective tax rate are computed by dividing some estimate of tax liability by a measure of before-tax profits or cash flow, however variations of ETR exist in the previous research. This research used GAAP based ETR. Minnick and Noga (2010) argue that ETR is good to measured long run tax avoidance, and since this research used 5 year data, then this measurement was deemed suitable.

\subsubsection{Tax Avoidance and Family Firms}

Wang et.al (2016) argue that corporate ownership is an important factor influencing decision making in business. Several previous research show that family business goals is driven by motivation to maintain legacy and to keep the family reputations (Habbershon, et.al, 2003; Carney, 2005; Zahra, et.al, 2004). Therefore Family business goals sometimes viewed as a multidimensionalconcept formed by economic and social aspects that com-bines two scales: economic versus non-economic orientationand family versus business orientation (Basco, 2017). This research showed that family business sometimes face dillema to maintain good reputation while in the same time need to conduct a profit maximization for a benefit of a business. Carney et.al (2015) stated that private family firms has different behavior with non public family firms. Public family firms has shareholder outside the family, and this shareholder demand more profit to the company. Therefore public family firms tend to do more business-oriented action, compare to family-oriented action.

Chen et.al (2010) research is one of the main research that can explain the family firms tax agressiveness. At first, it was thought that family firms is more agressive than non family firms. Chen et.al (2010) because family owners have substantially higher holdings, they benefit more from tax savings or rent extraction that can be concealed by tax aggressive activities. However the Chen's research result showed different things. The result showed that family firms tend to be less agressive. Family firms tend to protect the reputation, especially in the country in which family entrenchment is deemed not too important. Another research made by Gregorio et.al, (2016) indicate that as family firms move to second or third generation, these generations were less tax sophisticated, and tend to be 
oriented to business, so they conduct more agressive tax avoidance. However, for family firms with higher power or control, it will become less tax agressive.

Corporate governance may also impact family firms tax agressiveness. Steijvers \& Niskanen (2014) stated that the presence of efficent board of directors may reduce tax agressiveness. Therefore, these boards appear to reduce the tax aggressive behaviour of family firms in second or third generations. It is interesting to test whether the family ownership is affecting tax avoidance. Researcher construct hypothesis as follows:

\section{H1: Family Onwership}

\section{significantly affected tax avoidance}

\subsection{Firms Characteristics}

Hanlon and Heitzman (2010) stated that research regarding tax avoidance currently examine the relation between firmlevel characteristics and tax avoidance using a number of the proxies. In this research, we will use 4 company characteristics variable: (1) profitability, (2) size, (3) leverage, (4) age of the company.

\subsubsection{Profitability}

Minnick and Noga (2010) argue that a main reason why companies engage in tax management is to improve financial performance. If we looked at the bonus plan hypothesis, Higher level profit firm tend to increase the profit to improve their performance, and it will minimize several cost, i.e. is income tax (Godfrey, et.al, 2010). However, if we also looked at political cost theory, the profit firm will try to maintain their reputation to gain more investor confidence, and will minimize the use of aggressive method of earnings management (Scott, 2006). Wahab and Holland's (2012) research showed that profitability affected tax avoidance. However, Adhikari, (2006) and Taylor and Richardson (2013) research showed inconsistencies of the result. Since the result is still inconsistence, researcher predict no sign in the hypothesis. Researcher construct hypothesis as follows:

\section{H2: Profitability significantly}

\section{affected tax avoidance}

\subsubsection{Size}

Dyreng et al. (2008) suggest that firm size play a role in tax management, and they find that smaller firms have higher tax rates. Rego (2003) argues that larger firms can achieve economies of scale via tax planning and have the incentives and resources readily available to them to reduce the amount of corporate taxes payable. The previous research result, however showed inconsistencies, Minnick and Noga's (2010) research showed that firm size positively affected tax, if the measurement of tax 
avoidance is using GAAP ETR, it shows no significant influence if the measurement is using Cash ETR. Taylor and Richardson (2013) also showed no significant influence between size and tax avoidance. Measurement of size can be used several proxy, but natural logarithm of total asset is widely used proxy, so researcher decide to adopt it's as a proxy of size. Since the result is still inconsistence, researcher also predict no sign in the hypothesis. Researcher construct hypothesis as follows:

H3: Size significantly affected tax

\section{avoidance}

\subsubsection{Leverage}

High level of debt can also affected the tax avoidance of the company. Minnick and Noga (2010) argue that company with higher leverage used interest expense of liabilities to reduce the amount of income tax payable. Badertscher et.al (2013) stated that firms with greater leverage have less need to tax plan due to the tax benefits of debt financing. The research result still showed that leverage didn't significantly affected tax avoidance. Minnick and Noga's (2010) and Taylor and Richardson (2013) research showed that leverage didn't affected tax avoidance. However research conducted by Badertscher et.al (2013) showed that leverage positively affected tax avoidance, measured by GAAP ETR. The measurement of leverage using debt to equity ratio, since capital structure (debt or equity) become a reason of doing tax avoidance (Minnick and Noga, 2010; Hanlon and Heitzman, 2010) Since the result is still inconsistence, researcher also predict no sign in the hypothesis. Researcher construct hypothesis as follows:

\section{$\mathrm{H}_{4}$ : Leverage significantly affected}

\section{tax avoidance}

\subsection{Corporate Governance}

Desai and Dharmapala's (2006) research is one of research that try to elaborate corporate governance and tax avoidance. They argue that corporate governance affecting the tax avoidance, and it will affected the firm value. Hanlon and Heitzman (2010) also stated that tax avoidance involving manager's behavior and based on agency theory, manager will tried to achieve maximum utility by engineering the financial performance (Jensen 1993). Increase monitoring and incentives in governance will reduce "bad practice" and therefore reduce tax avoidance. This research will tried to elaborate several proxies, namely: (1) size of board of commissioner (2) proportion of independent commissioner (3) audit firms (4) audit committee.

\subsubsection{Size of Board of Commissioner}

Indonesia adopt two tier board system. In this system, the monitoring and 
executive function was separated. Monitoring function conducted by board of commissioner. The board of commissioners serves as an internal monitoring mechanism to protect the interests of stockholders (Jensen, 1993; Minnick and Noga, 2010). The board of commissioner can have inside and outside commissioner. Several previous research showed that larger boards with more inside directors tend to have more agency problems, since the commissioner have more power to be abusive and only act on interest of majority shareholder (Scott, 2006; Godfrey, et.al, 2013). Previous research still showed inconsistencies. Wahab and Holland (2012) didn't find the evidence that size of board affected tax avoidance. Minnick and Noga (2010) find a significant, but weak affected of size of board toward tax avoidance. Researcher construct hypothesis as follows:

Hs: Size of Board of Commissioner significantly affected tax avoidance

\subsubsection{Proportion of Independent Commissioner}

Indonesia board system used terminology of “independent commissioner" as an equal for outside director. Inside director provide several opportunity to increase aggressive behavior, and therefore will fail to control the company (Jensen, 1993). Outside director provide more monitoring mechanism, since the outside director is independent and not having direct or financial interest within company. Several previous research have proofed that percentage of outside director reducing the act of tax avoidance (Minnick and Noga, 2010; Taylor and Richardson, 2013; Armstrong, et.al, 2015). However, several previous research also failed to find any affected between proportion of independent commissioner toward tax avoidance (Wahab and Holland, 2012). Since the result is still inconsistence, researcher also predict no sign in the hypothesis. Researcher construct hypothesis as follows:

\section{H6: Proportion of Independent} Commissioner significantly affected tax avoidance

\subsubsection{Audit Firms}

External audit firms may affected tax avoidance practice of company. McGuire at.al (2013) argued that external audit firms might be include several tax expertise. Tax expertise will give advise company to reduce income tax legally. However, since it's difficult to find tax expertise data of auditor in Indonesia, this research will used Big 4 audit firm, to distinguish audit firms. Based on several previous research, Big 4 audit firms have more capable and competent resource qualified as a tax expertise, compare to non Big 4 audit firms. Previous research that tried to make inference of audit firms to tax avoidance is 
still rare. Research made by McGuire et.al (2013) showed that use of Big4 audit firms increase tax avoidance level of the firm. However, researcher will make no prediction on sign of hypothesis, since lack of previous research and literature. Researcher construct hypothesis as follows:

H7: Audit Firms significantly affected tax avoidance

\subsubsection{Audit Committee}

In Indonesia, audit committee is the special committee under board of commissioner. The role of audit committee is to give advise to board of commissioner relating to financial and audit matters, and also provide general monitoring mechanism on behalf of board of commissioner. Audit committee member usually had an accounting or financial expertise. Audit committee might have role on tax avoidance. There is no previous research regarding on audit committee role on tax avoidance, based on researcher knowledge. But if we used a political cost hypothesis, role of audit committee can reduce tax avoidance practice. Researcher construct hypothesis as follows:

\section{Hs: Audit Committee significantly}

\section{affected tax avoidance}

The research model can be described as follows:

Figure 1. Research Model

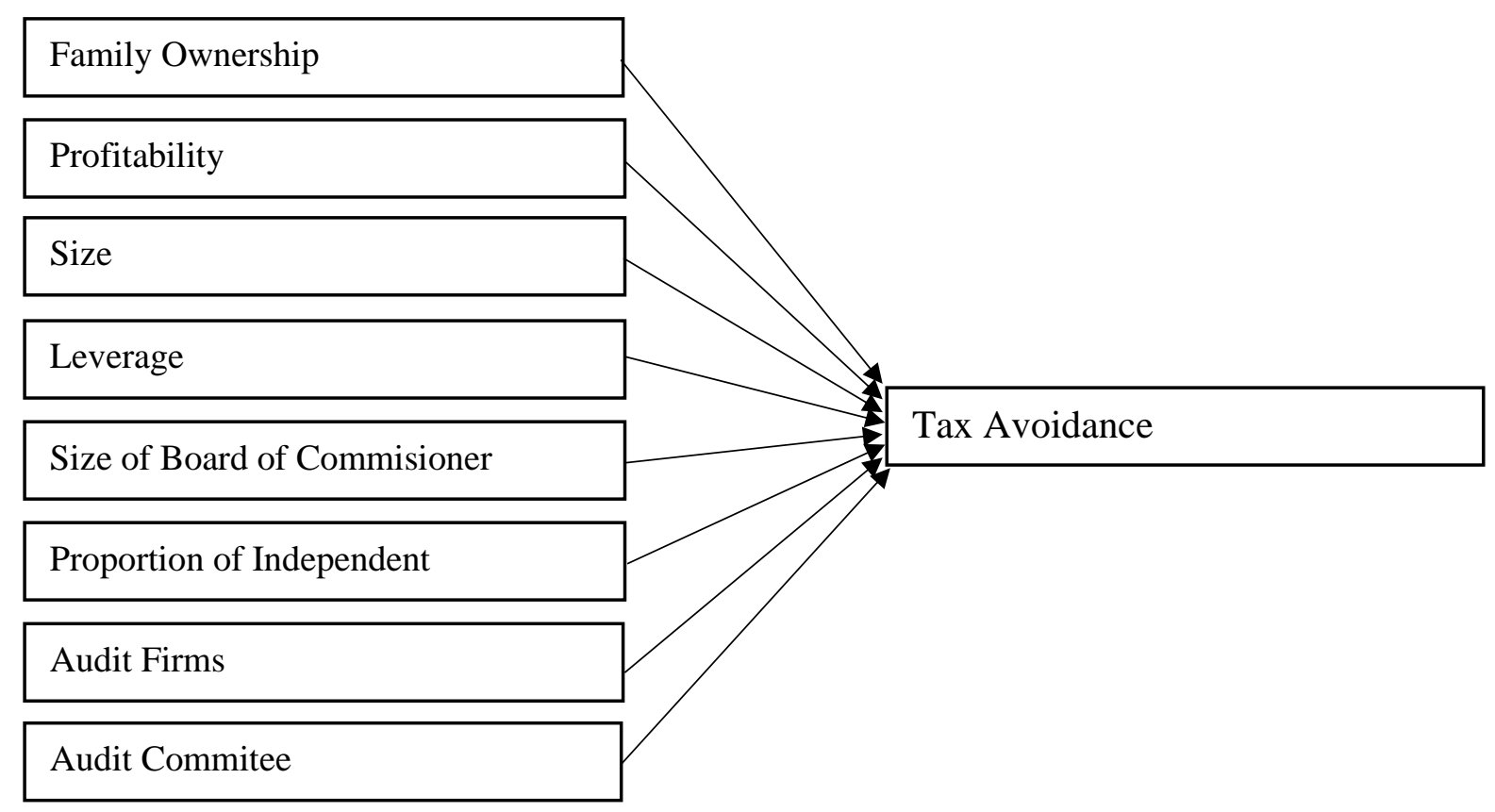




\section{RESEARCH METHODS}

This research uses the descriptive explanatory approach, following the quantitative methodology. The population in this research consists of all the companies listed on the Indonesian Stock Exchange, a total of 533 companies. Researcher select sample using purposive sampling method. Researcher will select companies that listed for 5 consecutive years in 2011 - 2015, excluding financial and mining companies, do not have ETR value > 1, and not suffering a net loss for 5 years in $2011-2015$. The total of family companies is 57 companies. The criteria to select the companies was taken from Sukmadilaga et.al (2016). Sukmadilaga et.al (in press) determined that the family business must have either of this criteria: (1) Have family ownership minimum $15 \%$ (2) Have family members acting as chair of board of commissioner or board of directors. From 57 companies, only 15 companies made to final sample. To make a fair comparison, researcher select 15 non family firms, which has the same company size as a family firms in the sample Final sample collected is 30 companies. The years 2011-2015 (5 years) are selected as the observation period. The data are collected using the financial statements of the companies for the years ending in 20112015.

To analyze data in detail and to make a better comparison accross all the group of companies, we make three data sets consists of : (A) Family firms only (B) Non family firms only (C) Both firms. Panel A and B will be a basis of comparison of analysis of company characteristics and corporate governance influence toward tax avoidance in family and non family firms. Panel $\mathrm{C}$ will be used to see if family ownership affecting tax avoidance. To answer all the hyphotheses we will use this model for panel $\mathrm{A}$ and $\mathrm{B}$ : 
While for panel $\mathrm{C}$, the model is as follows:

$T A=\alpha_{0}+\alpha_{1} P R O F I T+\alpha_{2} S I Z E+\alpha_{3} L E V+\alpha_{4} S I Z E \_B R D+\alpha_{5} I N D \_B R D+\alpha_{6} A U D+\alpha_{7} A U D \_C O M+\alpha_{8} F A M I L Y+\varepsilon$

Notes:

TA : $\quad$ Tax Avoidance, measured by GAAP ETR (Income Tax Expense / Pretax Income)

PROFIT: $\quad$ Profitability, measured by Return on Asset

SIZE: $\quad$ Size, measured by natural logarithm of total assets

LEV: $\quad$ Leverage, measured by Debt-To-Equity Ratio

SIZE_BRD: Size of board of commissioner, measured by number of member of board of directors

IND_BRD: Proportion of independent commissioner, measured by number of member of independent commissioner divided by number of member of board of directors

AUD: $\quad$ Audit firms, measured by 1 for Big 4 audit firms, and 0 for other.

AUD_COM: Audit committee, measured by number member of audit committee.

FAMILY: $\quad$ Family companies, measured by using dummy variables (1=Family firm, $0=$ Non family firms)

Data analysis will be conducted using multiple regression analysis. Classical assumpition tests in form of normality, multicolinearity, heteroscedasticty, and autocorrelation will be done to assure that the model fit before entering regression process. All the data analysis will be done by using E-Views 8.0 software.

\section{RESULT AND DISCUSSION}

This section will present research result based on the empirical data found by researcher. Researcher will first describe the descriptive statistics of this research, and then present the multiple linear regression result and analysis.

\subsection{Descriptive Statistics}

Based on the data found, the researcher can present the result on Table 1 below. Table 1 present 3 panel of data. From the table below we can see that mean value of family firms ETR is lower compare to non family firms. The mean differences is significant at $\alpha=10 \%$. However, the level of family and non family firms ETR is still

lower to current Indonesia's income tax rate (currently 25\%). From the corporate governance persepctives, we can see that average number of board of commissioner and percentage of independent comisioner is lower compare to non family firms. However, only mean difference in size of board of commissioner that statistically significant at $\alpha=5 \%$. Family firms in the sample mostly audited by Big4 audit firms, while non family firms in the sample were mostly audited by non big 4 audit firms. The difference sign is significant at $\alpha=1 \%$. There is no significant difference of number 
of audit committee member of family and non family firms. From the company characteristics, profitability of family firms is slightlt lower than non family firms, and the mean differences is statistically significant at $\alpha=5 \%$. However, family firms has low level of leverage compare to non family firms, and the mean differences is statistically significant at $\alpha=5 \%$. Size of companies in family and non family firms has no significant differences.

Table 1. Descriptive Statistics

\begin{tabular}{|c|c|c|c|c|}
\hline Variables & Min & Max & Mean & Std Dev \\
\hline \multicolumn{5}{|c|}{ Panel A: Family Business Only } \\
\hline AUDIT & 0 & 1,00 &, 5500 & ,50169 \\
\hline SIZE_BRD & 3,00 & 8,00 & 4,3667 & 1,62571 \\
\hline IND_BRD & ,33 & ,50 & 3888 & 06861 \\
\hline AUD_COM & ,00 & 5,00 & 3,0000 & 99149 \\
\hline LEV & 15 & 2,27 & 8156 & ,48900 \\
\hline PROFIT & ,00 & ,27 & ,0840 & 06744 \\
\hline SIZE & 26,55 & 30,84 & 28,7609 & 1,24115 \\
\hline TA & , 00 & | 41 & 1922 & 09023 \\
\hline \multicolumn{5}{|c|}{ Panel B: Non Family Business Only } \\
\hline AUDIT & 00 & 1,00 & ,1667 & ,37582 \\
\hline SIZE_BRD & 3,00 & 9,00 & 5,0333 & 1,67703 \\
\hline IND_BRD & , 00 & 71 & 3940 & 12827 \\
\hline AUD_COM & 00 & 4,00 & 2,8333 & ,88618 \\
\hline LEV & ,00 & 3,03 & 1,0625 & ,58287 \\
\hline PROFIT & 02 & ,66 & ,1126 & 12273 \\
\hline SIZE & 23,12 & 31,35 & 28,5490 & 2,00571 \\
\hline TA & 02 & ,43 & ,2132 & ,09098 \\
\hline \multicolumn{5}{|c|}{ Panel C: All Companies } \\
\hline AUDIT & 00 & 1,00 &, $3583 * * *$ & ,48152 \\
\hline SIZE_BRD & 3,00 & 9,00 & $4,7000 * *$ & 1,67833 \\
\hline IND_BRD & 00 & ,71 & 3914 & 10246, \\
\hline AUD_COM & , 00 & 5,00 & 2,9167 & 94008 \\
\hline LEV & , 00 & 3,03 & ,9391** & 54987, \\
\hline PROFIT & ,00 & ,66 & ,0983** & 09965, \\
\hline SIZE & 23,12 & 31,35 & 28,6550 & 1,66421 \\
\hline TA & ,00 & ,43 & ,2027* & ,09084 \\
\hline \multicolumn{5}{|c|}{$t=10$} \\
\hline$* *$ & it $\alpha=1 \%$ & & & \\
\hline$*$ & $\begin{array}{l}=5 \% \\
=10 \%\end{array}$ & & & \\
\hline
\end{tabular}

\subsection{Multiple Regression Analysis}

Before conducting multiple linear regressions, researcher conducted classical assumption test. Based on the classical assumption, there are problems of heteroscedasticity and autocorrelation. 
Since the model has heteroscedasticity and autocorrelation, researcher decide to adopt a robust regression model by using Heteroscedasticity Autocorrelation Correction (HAC). HAC will used a NeweyWest Method. Multiple linear regressions has been done with HAC-Newey West estimator, using Eviews 8.0 statistical software. The regressions equation provided to be as follows:

Table 2. Multiple Regression Results

\begin{tabular}{|c|c|c|c|c|c|c|c|}
\hline Variable & $\begin{array}{c}\text { Expected } \\
\text { Sign }\end{array}$ & Coef & Prob. & Coef & Prob & Coef & Prob \\
\hline & & Pane & $\begin{array}{l}\text { el A: Family } \\
\text { Companies }\end{array}$ & $\begin{array}{r}\text { Panel } B \\
\text { Cor }\end{array}$ & $\begin{array}{l}\text { on Family } \\
\text { anies }\end{array}$ & Panel C: & Companies \\
\hline C & (?) & 1.460 & $0.000 * * *$ & 0.408 & $0.007 * * *$ & 0.381 & $0.016 * *$ \\
\hline AUDIT & (?) & 0.088 & $0.001 * * *$ & -0.049 & $0.003 * * *$ & 0.088 & $0.001 * * *$ \\
\hline AUD_COM & (?) & 0.018 & $0.024 * *$ & 0.195 & $0.000 * * *$ & -0.006 & 0.277 \\
\hline DEBT & (?) & 0.112 & $0.000 * * *$ & -0.057 & $0.007 * * *$ & -0.003 & 0.419 \\
\hline IND_BRD & (?) & -0.441 & $0.026 * *$ & 0.157 & $0.040 * *$ & 0.061 & 0.278 \\
\hline PROFIT & (?) & -0.200 & $0.100 *$ & -0.521 & $0.000 * * *$ & -0.336 & $0.002 * * *$ \\
\hline SIZE & (?) & -0.048 & $0.000 * * *$ & 0.003 & 0.283 & -0.003 & 0.290 \\
\hline SIZE_BRD & (?) & 0.024 & $0.004^{* * *}$ & -0.022 & $0.002 * * *$ & -0.008 & 0.108 \\
\hline FAMILY & (?) & & & & & -0.071 & $0.003^{* * *}$ \\
\hline Adj $R^{2}$ & & & 0.266 & & 0.379 & & 0.093 \\
\hline F-stat & & & 4.069 & & 6.156 & & 2.351 \\
\hline Prob & & & $0.001^{* * *}$ & & $0.000 * * *$ & & $0.018^{* *}$ \\
\hline \multicolumn{8}{|l|}{ Notes: } \\
\hline \multicolumn{8}{|c|}{$* * * \quad:$ significant at $\alpha=1 \%$} \\
\hline & $* *$ & \multicolumn{6}{|c|}{ significant at $\alpha=5 \%$} \\
\hline & $*$ & \multicolumn{6}{|c|}{$\therefore$ significant at $\alpha=10 \%$} \\
\hline
\end{tabular}

From Table 2 above, we can see that from the three panel data, all the model were stastically significant. In the panel A, all variables are statistically significant, while in panel B only size that not statistically significant. Panel C - combination of all firms - showed that family firms negatively affected the ETR, which mean that family firms are tend to have more tax avoidance.
We can see that from this three panel data, audit firms has significant affected toward tax avoidance, however in panel $\mathrm{B}$, the sign is negative, while the other panels show the positive sign. Audit committee significantly affected tax avoidance in Panel A and B, but if the data combined, it showed no significant influence. From the board characteristics, independent board showed 
negative sign in Panel A, but positive sign in Panel B. Size of board of commissioner showed positive sign in Panel A, but negative sign in Panel B. The difference in coefficient sign prove to be very interesting, since in family firms, independent commissioner tend to influence more tax avoidance, while board of commissioner as a whole reduce tax avoidance. In non family firms, the results is reversed. Independent commissioner reduce tax avoidance, while size of board of commissioner increase tax avoidance. From company characteristics, higher profitability tend to increase tax avoidance. This result prove to be consistent accross three panel of data. Other company characteristics variable, debt and size showed less consistent results. Debt positively affected tax avoidance in family firms, but negatively in non family firms, while size of company only significantly affect tax avoidance in family firms.

\subsection{Discussion}

\subsubsection{Tax Avoidance in Family Firms}

This research showed several interesting results. Generally, family firms tend to have more tax avoidance rather than non family firms. This research result confirm the previous theory made by Chen et.al (2010). This research showed that in Indonesia, family companies more driven by motivation to increase the performance of company, rather than keeping he good reputation. Indonesia also still had problem with high tax corruption, so the awareness and compliance of tax in Indonesia are still low. From the company characteristics related variables, profitability, size, and leverage of company showed different results in family and non family firms. In all 3 panels, profitability showed negative sign, which means the higher the profitability, the lower the effective tax rate. This research result is the same like previous result made by Wahab and Holland (2012). This research also confirm the theory of bonus plan hypothesis, in which the management will seek a way to maximize the financial performance, by reducing several expense including tax expense.

\subsubsection{Tax Avoidance and Firms Characteristics}

Size showed negative results in family firms, which means that larger family firms tend to do tax avoidance, while in non family firms, size didn't significantly affect tax avoidance practice. This result is quite interesting, since the results in non family firms seems to support the political cost theory, in which big companies will trying to prevent "negative reputation" by not enganging into agressive action. This research result however, similar to result found by Minnick and Noga's (2010). Family firms research result however, showed that larger family firms posess more 
resources and knowledge to do more tax avoidance practice. The research results confirm previous research done by Dyreng et.al (2008), Rego (2003), and Minnick and Noga (2010).

Leverage, is significantly affected tax avoidance, and this result was in line with Minnick and Noga's (2010) and Taylor and Richardson (2013). There is an interesting difference, however, in a family firms we found there is a negative association between debt and tax avoidance, while in non family firms the association is positive. This research findings confirm that family firms and non family firms has different view on leverage and tax avoidance. Family firms' debt mostly are debt between related parties, and usually interest expense from the related parties cannot be deducted for tax purposes, while non family firms engaging in more non related debt, in which interest expense can be deducted for tax purpose, so it lowering the tax paid by company. Generally, This research showed that managers might be viewed debt as a burden for company performance (Gitman, 2006; Godfrey, et.al, 2010). Therefore the manager will choose to remove the burden, rather than utilize it as a tax avoidance tools.

\subsubsection{Tax Avoidance and Corporate Governance}

Corporate governance variables also showed several interesting results. From 4 variables analyzed, size of board of commissioner, independent commissioner, audit firms and audit committee affected tax avoidance. For size of board of commissioner and independent commissioner, the coefficient sign showed several contradictive results. For size of board of commissioner in family firms, it negatively affect tax avoidance, while in non family firms the results is positive. For independent commisioner in family firms, it positively affect tax avoidance, while in non family firms the results is negative. The result for board of commissioner in family firms seemed to be consistent with Minnick and Noga (2010) results. It's implied that family firm's board tend to discourage tax avoidance as a whole, but independent commissioner tend to encouraging more tax avoidance. This could confirm the previous results made by Hermiyetti and Manik (2013). Existence of independent commissioner in family firms is only for meeting government regulations, family owner has greater control over the company. However, the family board member still need to maintain company reputation, so it will maintain monitoring activities to reduce several risks in company. In non family firms, size of board commissioner positively 
affected tax avoidance, while independent commissioner negatively affected tax avoidance. This result showed similarity with Wahab and Holland (2012). This research also confirm previous theory made by Godfrey et.al (2013) that member of commissioner engaging in a tunneling activities, that increasing the wealth of majority shareholder. Independent commissioner in non family firms also showed its function in reducing tax avoidance, and this is in accordance with Minnick and Noga, (2010), Taylor and Richardson (2013), Armstrong, et.al (2015).

Audit firms is significantly affected tax avoidance, but there is a different coefficient sign between family and non family firms. In family firms, Big4 audit firms tend to advice tax avoidance, while in non family firms, the Big4 audit firms advice to reduce tax avoidance. In family firms, this research result confirmed McGuire et.al (2013) and also Chen et.al (2016) research. Chen et.al (2016) stated that family business not audited by Big4 has more chance to restate the financial statements voluntarily. While in the non family business, the Big4 audit firms tend to advice company to reduce its tax avoidance. Its implied that Big4 audit firms is more conservative in doing an audit, so the Big4 audit will advise the client to strictly follow tax rules, rather then to do a tax avoidance. Audit committee showed positive sign, which mean the more number of audit committee member in company, lead to higher effective tax rate. This research result are consistent in both family and non family firms. This results also showed that audit committee play a significant role in preventing agressive behavior.

\section{CONCLUSION}

This research showed that in general there is a relationship between company characteristics and corporate governance to tax avoidance practice. However, as we seen in the discussions, several variables showed different results in family and non family firms. In the company characteristics related variables, it is implied that family firms and non family firms motivation to do tax avoidance is based on profitability level, size and leverage didn't have the same effect in family firms and non family firms. Corporate governance related variables also showed different results. Size of board of commissioner and independent commissioner has opposite coefficient sign in family and non family firms. The results indicate that while independent commissioner in family firms cannot resist the family members influence in company, it can be truly "independent" in the non family firms. Size of board member in family also reducing tax avoidance in order to avoid negative reputation, while in non family firms, there is no additional need like 
in family members, so members will conduct tunneling mechanism to benefited majority shareholder. Audit firms also has different sign in family and non family firms. It showed clearly that there is a significance difference in governance structure of family and non family firms.

This research only able to select 15 out of 57 companies. The sample size perhaps is too small to generate a robust conclusions, so future research might expand the sample. Future research might tried to add several more proxies to better represent clearly the company characteristics and corporate governance related variables.

\section{REFERENCES}

Adhikari, A., Derashid, C., \& Zhang, H. (2006). Public policy, political connections, and effective tax rates: Longitudinal evidence from Malaysia. Journal of Accounting and Public Policy, 25, 574-595.

Armstrong, Chris; Blouin, Jennifer L; Jagolinzer, Alan D; and David F Larcker (2015). Corporate Governance, Incentives, and Tax Avoidance. Journal of Accounting and Economics 60 (August 2015): $1-17$.

Badertscher, B.A; Katz, S.P; and Sonja, O. Rego. (2013). The separation of ownership and control and corporate tax avoidance. Journal ofAccounting and Economics 5, 228-250

Basco, Rodrigo. (2017). "Where do you want to take your family firm?"' A theoretical and empirical exploratory study of family business goals', Business Research Quarterly (20), 28-44

Carney, M., 2005. Corporate governance and competitive advantagein family-controlled firms. Entrep. Theory Pract. 29, 249-265.

Carney, M., Van Essen, M., Gedajlovic, E.R., Heugens, P.P.M.A.R.,2015. What do we know about private family firms? A meta-analytical review. Entrep. Theory Pract. 39, $513---544$.

Chen, S., Chen, X., Cheng, Q., Shevlin, T., (2010) .Are family firms more tax aggressive than non-family firms? Journal of Financial Economics 95,41-61

Chen, K.L., Chang, S.H., Wang, T.S., (2016). 'Do Personnel Stability, Family Business and Auditor Influence Financial Restatement?', International Journal of Economics and Financial Issues, 2016, 6(1), 245-251.

Danny Septiriadi and Darussalam. (2007). Basic Concept of International Taxation. Jakarta: Danny Darussalam Tax Center.

Desai, Mihir A., and Dhammika Dharmapala. (2006) Corporate Tax Avoidance and High Powered Incentives. Journal of Financial 
Economics 79, no. 1 (January 2006): 145-179.

Dyreng, S., Hanlon, M., Maydew, E., 2008.

Long-run corporate tax avoidance.

Accounting Review 83, 61-82.

Gitman, L.J. (2006). Principles of Managerial Finance $9^{\text {th }}$ edition. New York: Prentice Hall. Inc.

Gregorio Sánchez-Marín María-José Portillo-Navarro José G. Clavel , (2016),"The influence of family involvement on tax aggressiveness of family firms", Journal of Family Business Management, Vol. 6 Iss 2 pp. -

Godfrey, Jayne; Hodgson, Allan; Tarca, Ann; Hamilton, Jane; and Scott Holmes. (2013). Accounting Theory $7^{\text {th }}$ edition. New York: John Wiley and Sons Inc.

Habbershon, T., Williams, M. and MacMillan, I. (2003), “A unified systems perspective of family firm performance", Journal of Business Venturing, 18, 451-465.

Hanlon, Michelle and Shane Heitzman, (2010) A Review of Tax Research. Journal of Accounting and Economics 50 127-178

Hermiyatti, and Manik, E.N. (2013). 'The Influence of Good Corporate Governance Mechanism on Earnings Management: Empirical Study in Indonesian Stock Exchange Listed
Company for Periods of 2006-2010', Indonesian Capital Market Review, Vol 5(1), $52-63$.

Jensen, M.C. (1993). The Modern Industrial Revolution, Exit, and The Failure of Internal Control Systems. The Journal of Finance 48, (1993): 831880.

Jones, Sally. 2012. Principles of Taxation for Business and Investment Planning 14th edition. New York: McGraw Hill. Inc

McGuire, S.T; Omer, T.C; and Dechun Wang. (2013). Tax Avoidance: Does Tax-Specific Industry Expertise Make a Difference? The Accounting Review 87,3 pp 975 - 1003.

Mills, L., Erickson, M., Maydew, E., (1998). Investments in tax planning. Journal of American Taxation Association $20,1-20$.

Minnick, K. \& Noga, T. (2010), Do Corporate Governance

Characteristics Influence Tax Management?, Journal of Corporate Finance16 (5), Elsevier, 703-718

Mohammad Zain. 2005. Manajemen Perpajakan Edisi ke-3. Jakarta: Salemba Empat.

Monterrey, J. and Sánchez, A. (2010), "Differences in tax aggressiveness between family and non-family companies", Spanish Journal of 
Finance and Accounting, 145, 6597.

Rego, S. (2003), Tax Avoidance Activities of

U.S. Multinational Corporations, Contemporary Accounting Research 20 (4), Wiley, 805-833.

Scott, William R. (2006). Financial Accounting Theory 6th edition. New York: Prentice Hall. Inc

Steijvers, Tensie and Niskanen, Mervi. (2014). 'Tax aggressiveness in private family firms: An agency perspective.', Journal of Family Business Strategy (5) 347-357

Taylor, Grantley and Grant Richardson. (2013). The determinants of thinly capitalized tax avoidance structures: Evidence from Australian firms. Journal of International Accounting, Auditing and Taxation 22 (2013) 1225

Wahab, Nor Shaifah Abdul and Kevin Holland. (2012). Tax planning, corporate governance and equity value. The British Accounting Review 44 (2012) 111-124

Wang, D., Ma,G., Song, X., Liu, Y. (2016). 'Political connection and business transformation in family firms: Evidence from China. Journal of Family Business Strategy (7) 117130

Zahra, S.A., Hayton, J.C. and Salvato, C. (2004), “Entrepreneurship in family 